\title{
E- commerce as an Added Value in the Tourism Services in Albania
}

\author{
Elton Noti, Phd
}

\author{
University “Alexander Moisiu”, Durrës, Albania; Email: eltonoti@gmail.com
}

Assoc. Prof Azeta Tartaraj

University “Alexander Moisiu”, Durrës, Albania; Email: azetatartaraj@yahoo.co.uk

\section{Doi:10.5901/ajis.2016.v5n1p329}

\section{Abstract}

\begin{abstract}
The tourism services in Albania, provided by the private sector, started after the 1990's, when the transition period in the country begun after 50 years in a centralized political and economical system. During this period the sector was faced with lack of experience in terms of providing tourism services, with poor infrastructure, lack of legislation, the bad conditions of hotels and other services required by tourists etc. One of the key elements that is needed for the marketing process is the use of information and communications technology, and e-commerce, which in the tourism sector are very useful and needed. The aim of this study is to identify how usable is the electronic commerce in Albanian tourism enterprises and how it affects the online tourism marketing. The study is descriptive, as well as explanatory. The research instrument used was a questionnaire. The sample consisted of $N=208$ participants, representatives of three types of tourism enterprises (accommodation units, travel agencies and restaurants). The study was based on five districts of Albania, where tourism is more developed, respectively: Tirana, Durres, Shkodra, Vlore and Sarande. The results show that in most of enterprises the web site offers the possibility of making online bookings, but not online payments. Also from the research was found that electronic commerce has a positive relation with online marketing.
\end{abstract}

Keywords: marketing, e-commerce, tourism, enterprise, Albania

\section{Introduction}

After the collapse of the communist regime in Albania, many political and economic changes occurred after the 1990-s. One of them was the liberalization of relationships of the country with the foreign ones, which created the first opportunity for the tourism development, with a new physiognomy. During this period the governments that came to power began to classify tourism as an important sector for the economic development.

The rapid economic recovery has encouraged investments in information and communication technologies (ICT-s) such as the internet access and other related technologies. However, regarding the e- commerce, including both goods and services, Albanians are still not too active buying online. But, over the last few years, the situation has been changed and online markets are getting more and more popular.

\subsection{Internet Service in Albania}

Positive is the fact that in Albania during last years the internet access is growing significantly and it directly may be considered as an advantage for the e - commerce. Also, the growing number of smartphones and Internet service users (3G / 4G) at a relatively low cost from mobile phone operators, is an advantage for the e-commerce.

According to AKEP (2015), the number of subscribers with broadband access from fixed networks by the end of 2014 was about 207,000 , compared to 183,000 in 2013 , representing an annual increase of $13.3 \%$. All the main operators of fixed internet in Albanian market have increased the number of subscribers for the year 2014. The number of mobile subscribers who have broadband access by using wireless networks ( $3 G$ USB cards/modems and handsets ) in 2014 was 1.4 million or $16 \%$ more than in 2013. The use of $3 G$ broadband access networks has been increased with 59 $\%$ for the access via USB / modem, and $12 \%$ through via mobile devices. The rate of penetration (number of subscribers per 100 inhabitants) of fixed network broadband access by the end of 2014, was $31.7 \%$ compared with $6.40 \%$ in 2013.

The expansion of the use of the Internet and other forms of electronic communication opens up significant opportunities for developing countries to develop their tourism and air transport sectors. They thereby cut out the costs of 
intermediaries (e.g. agency fees) and transaction costs and avoid the need for a direct commercial presence and its associated costs. Nevertheless, electronic marketing and trading have their own costs in terms of human and physical capital requirements. In countries where these requirements are in relatively short supply, the cost of electronic marketing and trading can be reduced if individual suppliers pool their resources. This could be coordinated, for instance, by national tourist authorities (WTO, 2001).

Tourism has a key difference from most other sectors of e-commerce - its consumer goes and collects the product at the point of production - i.e. the destination. Thus, the tourism sector avoids the need to deliver products around the world - a task that faces real logistical problems that have been a major source of customer dissatisfaction (WTO, 2001).

\subsection{Tourism Services in Albania}

According to data obtained from the Tourism Services Office, (An agency under the upervision of Minister Responsible for Tourism) for 2013, the estimated capacity of beds in the accommodation units was 28,721, in national level.

Regarding the travel agencies in Albania, statistics of the Ministry of Tourism and the National Registration Center for 2013 show that there are around 250 travel agencies operating in different cities of the country.

\subsection{The Aim of the Study}

The aim of this study is to identify how usable is the electronic commerce in Albanian tourism enterprises and how it affects the online tourism marketing

\subsection{Research Questions and Hypothesis}

\subsubsection{Research questions}

1- Does the electronic commerce affect positively the online marketing in tourism enterprises?

2- Do the Albanian tourism enterprises websites offer the possibility to make e-commerce?

\subsubsection{Hypothesis}

Rayport and Jaworski (2001) suggest that in order to be competitive in the electronic age tourism enterprises should be willing to use channels with technological nature, to create internal and external value, formulate strategies according to the technology and to organize their sources for the knowledge and relationships. In terms of marketing, communication and electronic commerce, are future issues. The following hypothesis (1) reflects the effort for understanding this relation in the Albanian context.

\section{$H_{1}$ : Electronic commerce will have a positive correlation with online marketing of tourism enterprises}

\section{Literature Review}

\subsection{The Electronic Commerce Process}

Many companies began to use the Internet not only for introducing or advertising their products but also to trade them. Worldwide, millions of companies have a chance to offer their goods and services from the internet to customers, as well as other companies. Active companies in the internet world are valued by their customers within and outside the country as a "store open 24 hours a day". E-commerce enables companies to have with relatively low cost more costumers.

In the virtual environment, the customers are distinguished by different behaviors from the traditional market customers. Therefore, for this category are required other approaches from them which are offered to the other category.

Regarding the buying phase, e-commerce is similar to the traditional purchase process and also includes the prebuying stages (which includes activities such as searching for information, alternatives review, evaluation and selection), purchase (includes the communication between customer and company, interaction, orders and transactions) and after purchase (includes different after-sales services, dealing with complaints, etc.) All these processes can take place completely or partly in an electronic market.

A database with the history of all transactions on the Internet could be the main source for the marketing sector for 
the tourism enterprises, thus helping them to determine the types of tourism products/services that they can offer, market segments which need to be addressed better and how the company is valued by consumers. By accessing other websites, a company can also get valuable information on supply and demand, competition and trade agreements, demographic data, domestic law and applicable technologies in international markets ( Mihălcescu and Sion , 2011).

Web and digitization of information, in parallel with the wide use of personal computers and the environment created the basis for the development of electronic commerce globally. During this time, traditional marketing techniques should be partially transformed and new ones were appearing. The development of marketing techniques based on the Web have been studied by various structures of scientific fields, noting particularly the marketing efforts of enterprises that are operating partially or entirely in the digital market which is enabled through web pages (Vora, 1998).

\subsection{E-commerce in the tourism sector}

The tourism industry consists of many business activities such as: accommodation services, travel agencies, restaurants, bars, various transportation activities for tourists, product manufacturing activities, crafts, cultural activities, sports, different parks (archaeological, natural, national, etc.), museums etc.

But this paper is focused on the accommodation sector, travel agencies and restaurants as the main activities in Albania which have a wide use ICT-s for business purposes.

Electronic marketing strategies have been extensively used and the pressure on different businesses to invest in technological applications regarding the production of tourism services has been increased. This trend is followed by the number of users of mobile devices that also is growing, and the interest for mobile technologies which is growing as well.

Above all, the expectations of consumers and market competition, are key elements of e-commerce in the tourism sector, while the small size of a majority of businesses and significant costs associated with the introduction of new technologies, constitute the main barriers for a big part of tourism businesses and in particular e-commerce.

Also, e - commerce is considered as a distribution channel for hotels, tour operators and travel agents. For example, hotel chains are applied electronic commerce processes, ranging from the promotion of their services, reservations of these services, and what is more important, conducting financial transactions online. These hotels usually use attractive websites, attractive graphics, virtual tours with 3D technology, interactive tools, etc, which make the customers to be attracted seeking to buy those services (Hend, 2002).

If we make a question why e-commerce in the accommodation sector is so important today?

Delmar (2014) has answered to that question claiming:

- It accelerates Internet usage worldwide

- The Internet is the lowest cost hotel-booking channel.

- Most travelers research hotel reservations on the Internet.

- Social media and online hotel reviews are an increasingly important decision factor.

\section{Methodology}

In this study is used the quantitative method approach through the use of surveys to collect data.

Research Context. The study was conducted in five districts of Albania, respectively in: Tirana, Vlora, Durres, Shkodra and Saranda. Although tourism services and related enterprises are not limited to these five districts, according to database for tourism and it's development, these areas have greater development of tourism industry during last year's. Sampling is based on a list of registered tourism enterprises in Albanian Tourism Association (ATA) and is referred to three types of tourism services: accommodation units, travel agencies and restaurants. Once the respective districts have been selected, then, it is taken a percentage from each district.

Sampling. In this study, was included one of the most common models of non probability sampling called quota sampling. Data analysis was realized through the statistical software SPSS 16.

Inclusion criteria. To participate in the study, participants must be over the age of 18 and had the primary responsibility to manage a tourism enterprise. They could be self owners, key managers or when they were not found, could be old employees. In other cases, have participated ICT specialists employed in the relevant enterprises.

Research tool. In order to realize the study as a research tool was used a face to face interview administered through a questionnaire. At the end of data collection, the final number of questionnaires was $n=208$.

Procedures of gathering data. The method of data collection for this study was that of a questionnaire completed through a face -to-face interview. 


\section{Results}

In this study $23.6 \%$ of the enterprises were located in Tirana, $15.9 \%$ in Vlora, $28.8 \%$ in Saranda, $17.3 \%$ in Durres and $14.4 \%$ were in Shkodra .

The three types of activities that have participated in this study, according to predetermined criteria, were: accommodation units at a rate of $56.2 \%$, travel agencies at $22.1 \%$ and restaurants at $21.6 \%$. In the field of tourism usually these are the types of activities that are studied. As regards the period of starting the business, the enterprises had an average of 10 years that they were operating in the market.

Regarding the status of participants, $40.4 \%$ of them were entrepreneurs, $38 \%$ were in the position of manager and $21.6 \%$ were in a different position, usually that of the economist, or ICT expert.

Regarding the opportunities provided by the website for e-commerce, the questionnaire used as an instrument for the study contained other statements that indicate the quality of the site (Table 1), but this paper is focused on the possibilities of online bookings, which were available to $68.5 \%$ of participants and online payments ( e- commerce ) with a relatively low level, only $37.5 \%$.

Table 1. The quality of website

\begin{tabular}{|l|c|c|c|}
\hline & $\underline{\text { Yes }}$ & $\underline{\text { No }}$ & $\underline{\text { I don't know }}$ \\
\hline Our website offers the opportunity to find detailed information about services / tourism products we offer. & $87.5 \%$ & $9.5 \%$ & $3.0 \%$ \\
\hline $\begin{array}{l}\text { The ability to find useful tourism information on the website such as : Info about the destination, information } \\
\text { on visas, airlines, weather forecasts, local events, etc }\end{array}$ & $61.3 \%$ & $32.1 \%$ & $6.5 \%$ \\
\hline The possibility of connection with other websites through (links ) providing useful information for tourism & $65.5 \%$ & $29.2 \%$ & $5.4 \%$ \\
\hline The ability to adapt / modify the product / service, according to specific needs & $70.8 \%$ & $23.8 \%$ & $5.4 \%$ \\
\hline The possibility of interaction / communication with the enterprise via the website (eg option " Contact Us" ) & $94.6 \%$ & $3.6 \%$ & $1.8 \%$ \\
\hline Online bookings & $68.5 \%$ & $26.8 \%$ & $4.8 \%$ \\
\hline E-commerce via the website & $37.5 \%$ & $57.7 \%$ & $4.8 \%$ \\
\hline Customer registration to the email list of the company to get the offers, news and different feeds. & $58.9 \%$ & $31.0 \%$ & $10.1 \%$ \\
\hline Information on the safety of the Site, for example, for online transactions, privacy rules etc. & $53.6 \%$ & $36.3 \%$ & $10.1 \%$ \\
\hline $\begin{array}{l}\text { The presence of multimedia elements on the website, such as: presentation of products / services company } \\
\text { with mobile figures, 3 -dimensional , video clips, ads, etc. }\end{array}$ & $59.5 \%$ & $28.6 \%$ & $11.9 \%$ \\
\hline
\end{tabular}

\subsection{The Relation between E-Commerce and Marketing}

In order to understand the relation between e-commerce and marketing was used the Spearman correlation. Table 2, shows that there is a moderate correlation between the operations of electronic payments and marketing $\left(r_{s}=393, p<.001\right)$ and between online reservations and marketing $\left(r_{s}=.377, p<.001\right)$. So, Hypothesis 1 ( $H_{1}$ : Electronic commerce will have a positive correlation with online marketing of tourism enterprises ) is suggested

Table 2. Relation between e-commerce and marketing

\begin{tabular}{llcc}
\hline & & Online bookings & E-commerce via the website. \\
\cline { 3 - 3 } Marketing & Correlation Coefficient & $.377^{* *}$ & $.393^{* *}$ \\
& Sig. (2-tailed) & .000 & .000 \\
**. The correlation is statistically significant at the level.001 (2-tailed). & 160 & 160 \\
\hline
\end{tabular}

\section{Conclusions}

The e- commerce continues to be one of the operations which are not much used by the Albanian tourism enterprises.

Generally, the opportunity of costumers to make bookings and online payments directly to the service providers via the Internet, using a credit or debit card, was considered a risk by the travel agencies, because less people require their 
support to buy tourism services.

Very important is the fact that although a large proportion (68.5\%) of the enterprises, had the opportunity to make online reservations through the website, still remain at low levels the possibility of e-commerce with only $37.5 \%$. partners.

The main functions of the web pages were to attract new customers and enable communication with international

Social networks are used widely by tourism enterprises for business communications.

$\mathrm{E}$-commerce is one of the most required services by international costumers

In most cases people are looking mostly at those webpages which enables them to make direct payments, even if the quality of is not too high.

\subsection{Recommendations}

- Increasing the number of the enterprises that should include the possibility of making online payments through websites, collaborating and negotiating with second level bank institutions.

- The Albanian Tourism Association should lobby and negotiate with senior representatives of banks on the issue of payment through credit cards according to international standards

- The staff of tourism enterprises should be trained, in order to be able to use perfectly the modern information technology.

- Revision of the Albanian legal framework on e-commerce in order to reflect the new global realities and accelerate the process of growth for this sector

\section{References}

AKEP.(2015). Raporti Vjetor i Veprimtarisë për Vitin 2014 [eng. Annual report of Activities 2014], Autoriteti i Komunikimeve Elektronike dhe Postare [eng. Authority of Electronic and Postal Communications], pp 38 - 40, Tirana

Demnar, José Ribeiro Sábio, (2014), E-Commerce for the Tourism and Hospitality Industry. [Online] Available: https://www.linkedin.com/ pulse/20140711182551-25743264-e-commerce-for-the-tourism-and-hospitality-industry (January 1,2016)

Mihalcescu, C., and Sion, B. (2010). The Main Applications of The Internet in Tourism Marketing, Romanian Economic and Business Review, pp 164 - 170, Romanian-American University.

Rayport, J. F. and Jaworski, B. J. (2001). E-Commerce. Boston: McGraw-Hill

Vora, P. (1998). Human factors methodology for designing Web sites. In Human factors in Web development, eds. C. Forsythe, E. Grose and J. Ranter.Mahwah, NJ: Lawrence Erlbaum Associates, Inc. Publishers

WTO (World Tourism Organisation). E-Business for Tourism - Practical Guidelines for Tourism Destinations and Businesses, pp 1-3, Madrid, 2001

WTO (World Tourism Organisation). "Tourism in the least developed countries", United Nations Conference on Trade and Development, pp 163 -185, Brussels, 2001 